\title{
Resilience of Tourism Entrepreneurship in the Disaster-Prone Area III of Mount Merapi-Indonesia through Social Development Approach
}

\author{
Citra Fathimah Salipi ${ }^{1,}$ Fentiny Nugroho*2 \\ \{citra.fathimahs@gmail.com ${ }^{1}$,fentiny2015@gmail.com ${ }^{2}$ \} \\ Postgraduate Program in Social Welfare, Universitas Indonesia, Depok-16424,
}

\begin{abstract}
The Merapi Volcano tour in Sleman Regency, Indonesia, is a mainstay of the tourism industry. This is one of the most active volcanos in the world. This study aims to analyze how entrepreneurship establishes tourism the aftermath of such a cataclysmic eruption of Mount Merapi in the midst of devastation and constraints. This research uses a qualitative approach and data collection is conducted through literature searches, indepth interviews with business operators of the Jeep Lava Tour, one of the owners of the coffee shops in Merapi, the officers of Department of Tourism in Sleman regency, and the Office of Cangkringan (local government). Previous studies have focused more on tourism development that were more synergetic with local government. However, this study emphasizes more on social development strategies conducted by resilient entrepreneurs in the tourism industry who are optimizing their individual capacities and developing communities in Cangkringan sub-district in disaster prone area.
\end{abstract}

Keywords: Community, entrepreneurship, social development, tourism

\section{Introduction}

The 2010 volcanic eruption caused considerable damage to Cangkringan sub-district, such as, houses damage, death of livestock, and destruction of public facilities and land in general. Heavy damage occured as the slope areas of Mount Merapi were filled with rocks and sand after the eruption. Such damage reduced the flow of tourists to visit the surrounding areas and this caused significant economic setbacks to many communities. In general, the tourism industry encourages people to enjoy travel activities, such as, visiting natural sites and attractions. It can also increase income and improve quality of life and the people's welfare surrounding areas. With all the natural potentials found in Indonesia, tourism is now growing rapidly across the country and contributing to social development. Social development as a planned social change process designed to promote the overall well-being of society in the context of a dynamic development process from many aspects, including social, economic, and environmental aspects [5].

There are several previous studies conducted in Batu, East Java (Indonesia). The main aspect of these studies was the benefit of tourism with a focus on the goal of increasing new avenues of employmenet in Batu City, where tourism was focused on cultural and historical attractions $\{4\}$. The other research discussed the formulation and impelementation of public policy set out in the Strategic Plan for Semarang District and its research method was to describe the observation results combined with likert scale (mixed method). There were 
various types of tourism developing in Semarang Regency, such as, industrial and educational tourism and Gedong Songo area has more cultural toursim $\{10\}$. The other research in Batu, East Java finds that in the impelementation of a social development program, there was correlation of social and economic aspects. This program was important for the community, government and individuals [11]. Research in previous studies were less focused on processes and strategies used in social development by community entrepreneurs for the economic development. Therefore, this study focuses more on the approach of social development, especially the strategies in the process of entrepreneurship formed to increase business in the tourism sector by optimizing the role of individuals and their impact on community progress in the districts of Cangkringan and Sleman. which are the disaster-prone areas of Mount Merapi. Individual and community strategies to promote societal welfare are the main focus of this research. To facilitate successful social development through the entrepreneurship system of community, actually the government needs to work with the business sector and the community to create more employment opportunities, especially for those living in the disaster-prone areas of Mount Merapi. However, to reach the greatest level of prosperity for the communities around Mount Merapi after the eruption, there are obstacles faced by the local communities in Cangkringan in developing tourism entrepreneurship. Based on this information, the following research questions derived for this paper is: How does the community build up entrepreneurship in Cangkringan after the 2010 eruption? What constraints of the entrepreneurial growth experienced by the people in the Cangkringan District, especially in the Disaster-Prone Area III of Mount Merapi?

\section{Method and Materials}

This research used a qualitative approach and an inductive logical pattern to derive results from facts and data from field findings coupled with theoretical thinking |7|. This approach was selected to obtain more in-depth information about the processes, obstacles, and benefits of tourism entrepreneurship in Cangkringan at Disaster Prone Aiea III of Merapi Volcano. This qualitative approach was used in this study to obtain in-depth and accurate data tailored to the conditions in the field $|7|$ A descriptive approach was also incorporated into this study. Descriptive research can provide explanations using words and numbers to present a profile (issue) and to develop a specific portrait of the situation, social arrangement, or relations. Data collection techniques consist of literature searches, in-depth interviews with business operators of the Jeep Lava Tour, one of the owners of the culinary coffee shops in Merapi, the Tourism Department in Sleman Regency, and the Office of Cangkringan (local government).

\section{Result and Discussion}

\subsection{Result}

The first eruption occurred on October 26, 2010 and it continued until November 5th. 2010. Mount Merapi was described as an explosive eruption that resulted in the release of glowing clouds as high as four kilometres in various directions. It was accompanied by the release of much material in the form of gravel ram and sand in some areas and large rocks 
around the slopes of Mount Merapi. The evaluation of the National Disaster Management Agency (BNPB) revealed that the human casualties from the eruption to be 347 , with the greatest number of victims, 246 people, in the Sleman Regency. The number of refugees reached 410,388 people [2]. There was $90 \%$ damage of buildings, facilities, and infrastructure in one Cangkringan District

In addition to the compensation and permanent occupancy, the local government of Sleman Regency continued to provide aid in the forms of cash, business loans, and other forms of aid, so that the communities can perform more resilience to fulfill their daily needs through entrepreneurship. By 2011 enterprise began to grow in the community when one business sector, Jeep Lava tour Merapi, began its operation. Jeep Lava Tour provides service along with its facility. A jeep can track all the way to regions of Merapi posts, Merapi Bunker and then be back. In an interview with one of the business actor of Jeep Lava Tour, he says :

In the beginning, there were only five jeeps; then in 2015, there were around 300. but now in 2017, Asosiasi Jeep Wisala Lereng Merapi (Jeep Association) reaches 26 communities, with a total of 620 jeeps. In 2015, there were 300 jeeps, but now in 2017 we have about 620. The increase is quite sharp (Informant business actor of Jeep Lava Tour Merapi).

Furthermore, he explains that from this type of business, the surrounding community has managed to take advantage of the jeep routes and has begun to open new tourist stops, such as, Sisa Hartaku Museum, which is a mini museum of remaining goods from the Mount Merapi eruption, the landscape of Alien stone, the Last World Castle, Merapi coffee shop, and souvenirs. Jeep Lava Tour business continues to experience a very significant increase in development, which clearly demonstrates that there is tourism selling power to be harnessed there. Initially, there was severe unemployment in the Cangkringan District before the 2010 eruption, but now economic and social conditions in the region are increasingly positive. Along with the jeep rental business, the others began to start other businesses, such as, the opening of mini museum, then old home land located on the slopes of Mount Merapi. Now there are stalls and souvenir shops, and an expansion into culinary arts that began with the original coffee of Mount Merapi in 2012, when the business actors of the Jeeps Lava tour started utilizing the route of their tour.

These tourist attractions are located in the Disaster-Prone Area III designated by Sleman Regent Regulation on Disaster Prone Area, Number 20, 2011 on the volcanic eruption prone area surrounding the Merapi Volcano. The land is privately owned so there is minimal government intervention in the travel and tourism system in this region $|8|$. Although there are regulations in disaster prone areas forbidding people to build any permanent building, in reality, there are some business owners who violate the rules and establish permanent buildings. Entrepreneurial competition in this area looks quite tight, yet it is also resilient.

The field findings from the local government sector, especially in Cangkringan subdistrict office, discover that they can only give permission for certain activities and there are issues related to giving permissions to build up establishments. The Sleman Tourism Office explains that the role of local government in Sleman District has not still been able to assess the maximum scale of destruction in the Disaster-Prone Area III of Cangkringan Village, particularly in Petung, Umbulhai jo and the surrounding areas. This is mainly because of the limitations or barriers made by people who are still close to the local government. Community is considered to have great ability to manage the tourism area, so government intervention is quite limited; however, actually the community still needs the government to play role as facilitator and the parties that control the tourism industry on the slopes of Mount Merapi

The income of people, such as, the jeep owners, culinary businessman, souvenir sellers, and other businesses are likely to increase over years. Moreover, the business owners have 
never experienced a decline in income due to the aggressive marketing of Mount Merapi tourism conducted by the local community. One activity which the Sleman District Tourism Office has never done is to hold a tourism exhibition or expo in various cities in Indonesia to sell panoramas and introduce the popular Jeep Lava Tour on the slopes of Merapi. Such activities can only be conducted by enhancing the synergy among business actors (individuals), communities, and government.

\subsection{Discussion}

\subsubsection{Tourism Sector}

Local people have valuable knowledge about the natural and cultural phenomena around them. However, they do not have financial ability or qualified expertise to manage or be directly involved in tourism activities that are based on nature and culture. Local people should be actively involved in tourism development. Tourism is now expected to provide more opportunities and access to local communities to develop businesses that support tourism such as craft shops, souvenir shops, food stalls, and others, so that the local communities can benefit more and even directly from tourists to improve the their welfare. The level of community members' involvement in tourism is very different from one person to another and depends on the type, experience, knowledge, and skills possessed by the individual or the local community [6]. Similar with the Cangkringan community, sustainable tourism where local communities act as business managers require governmental assistance. Self-reliant entrepreneurs that have run business since the eruption in 2010 are becoming the successful ones, evidenced by ever-increasing incomes. However, the support of the government sector is still considered to be very necessary and highly expected in accordance with the vision and mission of the local government of Yogyakarta, as defined in Article 3, Paragraph 4 of Law Number 1 of 2012, regarding the objectives of regional tourism development. These include the following [3]:

a. Creating creative and innovative culture-based tourism as a priority sector and regional development priority,

b. Increasing Gross Domestic Product, Regional Foreign Exchange, Gross Regional Domestic Product, local income, and community income while maintaining environmental sustainability.

c. Embodying a tourism industry that is capable of driving local economies through increased investment in tourism, cooperation among tourism enterprises, expanding employment, and implementing efforts to support environmental conservation and community empowerment.

As mentioned above, the objectives of regional tourism development will not work optimally without the participation of individuals, communities, and government. So far, the government assistance, like supervision and training for the development of tourism businesses has been insufficient.

\subsubsection{Social Development}

Social development as a planned social change process designed to promote the overall wellbeing of society in the context of a dynamic development process from all sides. That is, social development cannot be done from only one perspective, but must represent many sides. There are several characteristics of social development. Firstly, social development is a dynamic process that targets societal improvement change. A community must be able to achieve these changes independently through an intervention program. Secondly, the process 
of social changes in social development is progressive, and must have program implementation in order to continue growing for the sake of the community welfare and selfreliance [4]. From social development approach, the development of local tourism is a dynamic development process which must include many aspects, namely, social, economic, environmental and cultural aspects,

\subsubsection{Social Development Strategies}

Social development strategy is categorized into three aspects [5]:

1. Social Development by Individuals

In this case, human welfare will be more enhanced when individuals can exercise their interest (their welfare). This is a fundamental principle in the views of western individualists and basic in the modern capitalist economic system. Proponents of this view believe that the welfare of a society can be lifted as individuals seek to improve their own welfare. However, this approach will only be effective if there is strong economy that can provide opportunities for people to function as rational economic actors. Individuals can only meet their needs and their families' if employment is available and pays adequately to leave the poverty level, gives opportunities to conduct entrepreneurship, and there is a future for investment.

2. Social Development by Community

The proponents of this view believe that people and communities have an inherent capacity to organize themselves to ensure that needs are met, their problems can be solved, and opportunities can be created to improve lives. To achieve these purposes they need to work together and have the same goals so that they can have control over local sources and affairs. It is also good for those who maintain external sources to promote social development at the local level

3. Social Development by the Government

The notion that social development can be adopted by the government with its specialized agents, such as, policy makers, planners, and administrators, forms the basis of a static or state approach to social development. Based on collective ideology, the proponents of this strategy believe that the state represents the interests of society as a whole and the state has a responsibility to raise the welfare of all its citizens. Proponents of this approach believe the government is collectively owned by its citizens and represents their interests; the state is a very important collective form. The results of interviews and observations conducted with several informants confirm that strategies offered to achieve social development have been maximized by the local community, especially the initiatives and innovations of the community in the Cangkringan District. The individuals as the entrepreneurs play an important role. They initiate creative business using the local potentials, maximizing nature, environment and local culture. Unfortunately, the government has not provided adequate support. Otherwise, the tourism business would improve the people 's welfare more significantly.

\subsubsection{Entrepreneurship of the Community}

"Entrepreneurship is the essence of economy of a nation The entrepreneurial spirit is essential to create better conditions for individuals or groups of people that should be able to contribute a positive value to the wider community by encouraging others and stimulating the national economy" [9]. If a group of individuals comes from a lower class (weak economic community), then there will be an increase in social prosperity and decrease of inequality among the individual and community groups. The increased group prosperity occurs because of the efforts that involve a community of entrepreneurs [ 10]. 
Concept of a creative economy is part of new economic era where the main pillars are information and creativity, where ideas and stocks of knowledge of human resources are major products in the economy [11]. Development is accompanied by the potential of natural resources and human resources to be evaluated and controlled by the government to generate a creative economy be strong enough to enter the era of globalization The potentials of natural resources used by the people of Cangkringan basically has its own selling points for tourists. By leveraging the existing environment and services, jeep tour business operators claim to have continually increased profits over the years. One of the jeep lava tour owners describes about the entrepreneurial process in the following interview:

We first established this business in 2011 because we could see the potential of a nature after the Mount Merapi eruption; so yes we had the idea to start a tour. First we bought one or two second hand jeeps from friends and acquaintance. After a long time, 1 now have 15 jeeps to rent for this four of Merapi. There is also an association for this, and currently there are 26 communities that participate in this association. It is growing over time and praise the lord (hamdalah). I used to work as car engineer (informant from the Jeep Lava Tour).

Further, he also talked about recent obstacles, such as, the lack of assistance from the Regional Government of the Sleman District:

In addition to the obstacles of price competition, we need education on how to further develop a business. We need supervision and assistance from the Sleman local government; it. is still not available, except for being able to acquire a driving license for jeep drivers. In fact, the jeep service sector requires quality control to assure the safety of tourists since the jeeps are basically old vehicles. We need guidance for how to guide tourists and English training for our guide, (informant of the Jeep Lava Tour Merapi business).

To be able to inform the tourists about the eruption of Mount Merapi and the surrounding culture would provide more value to the business. The price competition among businesses such as the Jeep Lava Tour is natural, but they have touched on other needs that local government should be active in providing resources for meeting those needs. The people interviewed that are engaged in culinary businesses mention the same things and one expresses huge expectations for the government to support their business and identifies obstacles he has encountered, with the following statement:

I hope that the Sleman District government, in particular, can provide training or workshops for people to start their business. So that the government not only gives aid in the form of cash, I think other people receive motivation to try entrepreneurship because this region is their place of origin. So it is necessary to raise awareness and encourage the entrepreneurial spirit of the community, because this place has a quite large potential. However, there are other problems, such as, the government status of the Disaster Prone Area that prohibits people from establishing permanent buildings. So local people still need some assistance to establish a culinary signature that attracts tourists to this place and other attractions. In disaster prone area III, there is one tourist attraction that has permanent structures and many hectares of land area. It's so not fair to the other people who want to develop their business, (informant interviews at the Merapi coffee shop).

Based on the in-depth interviews conducted, the local business people seem to be eager and motivated, which is a great sign of readiness to start a business. Establishing business is still considered not in line with the mission of the government of the Special Region of Yogyakarta as set forth in Article 3, paragraph 4 of the Regional Regulation No. I of 2012. Through observations, it is clear that the government has not fully provided tourism with facilities yet; the people must be well-prepared and self-sufficient as they strive to develop their own businesses in the tourism sector. 
In addition, at present the local government manage taxes in early 2017 applied by the District Government of Sleman. However, it is deemed as an action taken too late by the government. In fact, if the local government and community of Cangkringan were well integrated, they can increase the number of tourists to the area and increase incomes for both local revenue and the community. This type of growth will also improve other aspect of daily life, such as, education and health. And this is the nature of social development approach, which integrates development of social, economic, natural and cultural aspects.

\section{Conclusion}

After the devastated 2010 eruption of Merapi, people began to apply creative ideas and innovations to the sector of natural tourism attractions of Mount Merapi to generate new businesses and new jobs. Starting in 2011 with Jeep Lava Tour operation, which utilized the natural potentials after the eruption, people became entrepreneurs and began developing new attractions and other new businesses in Cangkringan along the jeep travel routes. Currently, aside from the increasing rental business of the Jeep Lava Tour, the others continue to open new businesses. However, there are constraints for businesses in the Disaster-Prone Area III Cangkringan, such as, competition; the governmental designation of a disaster risk region around Mount Merapi, which is a burden for people wanting to set up permanent buildings for business; lack of government support for entrepreneurship development, especially in Sleman District lacking of personnel for mentoring and assisting the entrepreneurs. The government should be able to use its existing rules as the basis for the development of tourism businesses sector. There is a great need for stronger strategy, not only by individual and community strategies, but also by government to restore economic empowerment and achieve welfare in Cangkringan, Sleman.

\section{Acknowledgments}

The authors would like to express their great gratitude to Universitas Indonesia for supporting the research under a grant scheme Hibah Publikasi Intemasional Tcrindeks untuk Tugas Akhir Mahasiswa (Hibah PITTA)

\section{Reference}

[1] Afif. F, (2013). Kewirausahaan dan ekonomt kreatif Retrieved from https://sbm.binus.ac id/2013/04/06/kewirausahaan-dan-ekonomi-kreatif/.Binus University

[2] [Geological Agency of the Ministry of Energy and Mineral Resources. (2016). Data dasar gunungapi merapi. Retrieved from http://www.vsi.csdm.go.id/index.php/gunungapi/data-dasargunungapi/542-g-merapi?start $=/$

[3] I .aw No. 1 of 2012 on Master Plan Tourism Development of Special Region of Yogyakarta (Id).

[4] Luthfi, R.R. (2009). Peran pariwisata terhadap kesejahteraan masyarakat di sektor lapangan pekerjaan dan perekonomian (studi kasus : kola ba!u) Journal ilmiah mahasiswa Feb. Universitas Brawijaya. Indonesia.

[5] Midgley, J. (1995). Social development: The developmental perspective in social welfare. Thousand Oaks. CA: Sage Publications.

[6] Nengah, S, I (2006). Ekowisata hutan mangrove dalam pembangunan pariwisata berkelanjutan: 
Studi kasus di Mangrove Information Center, Desa Pamongan Kecamatan Denpasar, Kota Denpasar (Unpublished, master dissertation), Universitas Udayana, Indonesia.

[7] Neuman, W. L. (2006). Social research methods: Qualitative and quantitative approach (6th Ed.) Boston: Allyn and Bacon.

[8] Sleman Regent Regulation on Disaster Prone Area, Number 20, 2011. (Id )

[9] Suryana. (2014). Kewirausahaan kiat dan proses menuju sukses. Jakarta: Salcmba Empat

[10] Suseno. (2003). Pengelolaan ttsaha pembenihan ikan mas. Jakarta: Pcnebar Swadaya

[11] Nugroho. F., Kusumastuti, R,. Salipi, C.F.. Wijayanti. L., Alifa, S. (2017). Improving the quality of heal apples as specialty corps to build competitive advantages in free trade (in Batu, East Java-Indonesia). International Journal of Applied Business and Economic Research. Vol. 15. 